The Neuroscientist (Invited Review)

\title{
Calcium dynamics and circadian rhythms in suprachiasmatic nucleus neurons
}

by

Masayuki Ikeda

Department of Molecular Behavioral Biology, Osaka Bioscience Institute, 6-2-4 Furuedai, Suita, Osaka, 565-0874, Japan

Running title: Intracellular $\mathrm{Ca}^{2+}$ regulates mammalian circadian clock

3 Figures

0 Tables

Send correspondence to:

Masayuki lkeda, Ph.D.

Department of Molecular Behavioral Biology, Osaka Bioscience Institute, 6-2-4 Furuedai, Suita, 565-0874 Osaka, Japan

Tel: +81-6-6872-4851

Fax: +81-6-6872-2841

E-mail: msikeda@obi.or.jp 


\section{Summary}

The hypothalamic suprachiasmatic nucleus (SCN) has a pivotal role in the mammalian circadian clock. SCN neurons generate circadian rhythms in action potential firing frequencies and neurotransmitter release, and the core oscillation is thought to be driven by “clock gene” transcription-translation feedback loops. Cytosolic $\mathrm{Ca}^{2+}$ mobilization followed by stimulation of various receptors has been shown to reset the gene transcription cycles in SCN neurons, whereas contribution of steady-state cytosolic $\mathrm{Ca}^{2+}$ levels to the rhythm generation is unclear. Recently, circadian rhythms in cytosolic $\mathrm{Ca}^{2+}$ levels have been demonstrated in cultured SCN neurons (Ikeda and others Neuron 38:252-263, 2003). The circadian $\mathrm{Ca}^{2+}$ rhythms are driven by the release of $\mathrm{Ca}^{2+}$ from ryanodine-sensitive internal stores and resistant to the blockade of action potentials. These results raise the possibility that gene translation/transcription loops may interact with autonomous $\mathrm{Ca}^{2+}$ oscillations in the production of circadian rhythms in SCN neurons. 


\section{Introduction}

Daily temporal patterns from cellular activities to animal behaviors are largely governed by the endogenous clock system, which has been proposed to be driven by gene transcription-translation feedback loops. The circadian oscillations in the "clock genes” have been observed in a wide range of systems, from unicellular organisms to mammalian cells and from peripheral organs to the central nervous system, although their DNA sequences are variable across species (Kondo and Ishiura 1999; Yamazaki and others 2000; Panda and others 2002a). Cytosolic free $\mathrm{Ca}^{2+}$ is a general intracellular messenger that regulates diverse cellular processes, including enzymatic activities, membrane potentials, secretions, and gene expressions, and is one of the candidate intracellular messengers involved in circadian rhythms. Although the contribution of cytosolic $\mathrm{Ca}^{2+}$ signaling in the regulation of the circadian clock has been extensively studied in diverse organisms, including unicellular organisms and plants (Goto and others 1985; Johnson and others 1995; Hasegawa and others 1999), no commonalities in the $\mathrm{Ca}^{2+}$-mediated signaling processes have been described among the various circadian clock systems.

In mammals, the hypothalamic suprachiasmatic nucleus (SCN) is known to have a core role in the generation of circadian rhythms because lesions of the SCN result in arrhythmic circadian behaviors under time cue-free conditions (Moore and Eichler 1972; Stephan and Zucker 1972). In mice SCN, the clock gene products BMAL1 and CLOCK are basic helix-loop-helix PAS transcription factors that form heterodimers and bind to the E-box enhancers upstream of Per and Cry genes to activate their transcription (Antoch and others 1997; King and others 1997; Tei and others 1997; Honma and others 1998; Sangoram and others 1998; van der Horst and others 1999; Jin 
and others 1999; Kume and others 1999). The protein products PER and CRY form heterodimers and translocate into the nucleus to inhibit transactivation by CLOCK/BMAL1. A protein product of Dec gene families recently found in the SCN, is also a basic helix-loop-helix PAS transcription factor, and thus is hypothesized to organize an additional molecular loop in the SCN clock (Honma and others 2002). One cycle of the molecular loop is assumed to generate a circadian cycle, called a "core loop” (Shearman and others 2000; Reppert and Weaver 2002; Honma and Honma 2003).

The SCN receives glutamatergic projections from retinal ganglion cells, and thus the core loop is synchronized to environmental light-dark cycles (12:12 hour cycles under common breeding conditions). In animals maintained in constant darkness or even in the in vitro SCN, the core loop maintains a circadian oscillation, demonstrating the self-sustained circadian nature of these gene transcription-translation cycles. A light pulse given during the active phase of nocturnal rodents kept in constant darkness or glutamate stimulation in the in vitro SCN during the corresponding circadian timing (i.e., the subjective night) can reset the core loop oscillations. Because $\mathrm{Ca}^{2+}$ influx is an initial cellular event in response to glutamate stimulation, cytosolic $\mathrm{Ca}^{2+}$ signaling has been proposed to be one of the intracellular messengers conveying environmental time signals to the endogenous clock, although the mechanism underlying the regulation of clock genes by cytosolic $\mathrm{Ca}^{2+}$ is not fully understood.

The core loop in the SCN may regulate diverse physiological events such as action potential firing rhythms (Inouye and Kawamura 1979; Green and Gillette 1982) and rhythmic secretion of arginine-vasopression and vasoactive intestinal polypeptide (Earnest and Sladek 1986; Shinohara and others 1995). These electrical and humoral 
outputs from SCN neurons may ultimately synchronize circadian behaviors (Silver and others 1996a; Aston-Jones and others 2001). Despite the successful cloning of several clock genes, the link between the gene transcription-translation cycles and oscillations in physiological activities of SCN neurons is still unclear. Recent findings that cytosolic $\mathrm{Ca}^{2+}$ concentrations oscillate with a circadian profile in SCN neurons (Ikeda and others 2003a) raise the possibility that mechanisms underlying $\mathrm{Ca}^{2+}$ homeostasis in SCN neurons may be principal targets for clock gene regulation (Honma and Honma 2003). If so, cytosolic $\mathrm{Ca}^{2+}$ may be a key intracellular messenger of both input to and output from the core of the mammalian circadian clock.

In this article, recent studies concerning intracellular $\mathrm{Ca}^{2+}$ signaling in SCN neurons are reviewed and the technical background underlying the recent findings of circadian $\mathrm{Ca}^{2+}$ rhythms in SCN neurons (Ikeda and others 2003a) is described. Based on these, hypothetical interactions between $\mathrm{Ca}^{2+}$ signaling and the core loop are discussed with regard to the importance of $\mathrm{Ca}^{2+}$ signaling cascades in the organization of circadian rhythms in SCN neurons.

\section{Nocturnal light causes changes in cytosolic calcium levels via retinohypothalamic transmission: a key intracellular signal for the resetting of the circadian clock}

SCN rhythms are tightly coupled to environmental light-dark cycles via the mono-synaptic projection from melanopsin-positive retinal ganglion cells (Gooley and others 2001; Berson and others 2002; Hattar and others 2002; Provencio and others 2002), the retinohypothalamic tract (RHT; Rusak and Zucker 1979; Fig. 1). The major neurotransmitter conveying photic information to the SCN is glutamate (Cahill and 
Menaker 1989a,b; de Vries and others 1993) although the pituitary adenylate cyclase-activating peptide also functions as a secondary neurotransmitter to the SCN (Hannibal and others 1997; von Gall and others 1998; for review Hannibal 2002). All three subtypes of glutamate receptors, a-amino-3-hydroxy-5-methyl-4-isoxazole-propionic acid (AMPA), kainate, and $N$-methyl-D-aspartate (NMDA) receptors, are expressed on SCN neurons and may function in RHT transmission (Takeuchi and others 1991; Gannon and Rea 1994; Jiang and others 1997; Schurov and others 1999; Michel and others 2002; Ikeda and others 2003b; Moriya and others 2003). The postsynaptic membrane of glutamate-receptive neurons such as this is generally depolarized by $\mathrm{Na}^{+} / \mathrm{Ca}^{2+}$ influx via non-NMDA receptors, and subsequently depolarized further by $\mathrm{Ca}^{2+}$ influx through NMDA receptor-linked channels followed by the glutamate stimulation. The $\mathrm{Ca}^{2+}$ influx through NMDA receptor-linked channels in SCN neurons may be the most critical step for clock regulation via RHT transmission, because NMDA receptor antagonists block light-pulse-induced phase shifts in locomotor activity rhythms, application of NMDA to brain slices containing the SCN during early subjective night produces a delay-shift, and application of NMDA during late subjective night produces an advance-shift, similar to the circadian profile of light-pulse-induced behavioral phase shifts (Ding and others 1994).

SCN neurons also express various other receptors that may interact with the glutamatergic system and modulate cytosolic $\mathrm{Ca}^{2+}$ levels. For example, serotonin (5-HT) 1B receptors expressed presynaptically on RHT terminals and 5-HT 1A/7 receptors expressed postsynaptically on SCN neurons both inhibit RHT transmission (Pickard and others 1996, 1999; Jiang and others 2000; Smith and others 2001). The 
$\mathrm{Ca}^{2+}$ transient caused by RHT stimulation in acute SCN slices (Flett and Colwell 1999) and glutamate-induced $\mathrm{Ca}^{2+}$ influx in cultured SCN neurons (Quintero and McMahon 1999) are significantly reduced by 5-HT agonists. Therefore, a 5-HT-induced reduction in glutamate-induced $\mathrm{Ca}^{2+}$ responses in SCN neurons may be the mechanism by which 5-HT inhibits light-pulse-induced behavioral phase shifts (Pickard and others 1996; Ying and Rusak 1997; for review, Rea 1998). Similar to postsynaptic 5-HT receptors, stimulation of orphanin-FQ/nociceptin receptors, which are expressed on the majority of SCN neurons, may activate $\mathrm{K}^{+}$currents and inhibit NMDA-induced $\mathrm{Ca}^{2+}$ influx (Allen and others 1999). Again, the inhibitory effects of orphanin-FQ/nociceptin on NMDA receptors may be the mechanism by which orphanin-FQ/nociceptin inhibits light-pulse-induced behavioral phase shifts (Allen and others 1999). These data suggest that changes in glutamate-induced $\mathrm{Ca}^{2+}$ mobilization in SCN neurons due to interactions with other receptor systems determine the total potency of RHT transmission and magnitude of the circadian phase shifts.

The majority of SCN neurons synthesize GABA and receive GABA projections, and thus GABA is thought to be a principal neurotransmitter within the SCN (Perez de la Mora and others 1981; Okamura and others 1986; Decavel and van den Pol 1990; Moore and Speh 1993; Buijs and others 1994). In addition, an indirect retinal input onto SCN neurons is mediated via the geniculo-hypothalamic tract (GHT; Harrington and Rusak 1989; Zhang and Rusak 1989; Edelstein and Amir 1999), which also releases GABA onto SCN neurons (Harrington and others 1987; Moore and Speh 1993). The dominant GABA receptor subtypes in SCN neurons are $\mathrm{Cl}^{-}$permeable ionotropic receptors, the $\mathrm{GABA}_{A}$ receptors $\left(\mathrm{GABA}_{\mathrm{A}} \mathrm{Rs}\right)$. Stimulation of $\mathrm{GABA}_{\mathrm{A}}$ Rs generally triggers influx of $\mathrm{Cl}^{-}$into the cells and membrane hyperpolarization, which inhibits 
neuronal excitation. The function of $\mathrm{GABA}_{\mathrm{A}} \mathrm{Rs}$ in SCN neurons may not be this simple, however, because Wagner and others (1997) have observed that activation of $\mathrm{GABA}_{\mathrm{A}} \mathrm{Rs}$ produce depolarization during the day and hyperpolarization during the night in adult rat SCN neurons. This difference in $\mathrm{GABA}_{\mathrm{A}} \mathrm{Rs}$ function has been suggested to be due to a day-night difference in intracellular $\mathrm{Cl}^{-}$concentration that may produce $\mathrm{GABA}_{\mathrm{A}} \mathrm{R}$-mediated $\mathrm{Cl}^{-}$efflux (i.e., depolarization) or $\mathrm{Cl}^{-}$influx (i.e., hyperpolarization) in SCN neurons (Wagner and others 1997, 2001). In dispersed cultures of SCN neurons, daily stimulation of $\mathrm{GABA}_{\mathrm{A}} \mathrm{Rs}$ synchronizes the dissociated circadian rhythms in each individual SCN neuron (Liu and Reppert 2000). This effect is not due to an inhibitory action (i.e., decreasing of firing frequency) via $\mathrm{GABA}_{\mathrm{A}} \mathrm{Rs}$, because the metabotropic GABA receptor $\left(\mathrm{GABA}_{B} \mathrm{R}\right)$ agonist baclofen inhibits action potential firing both during the subjective day and night without causing a significant phase shift (Liu and Reppert 2000). Our group found that, at least at a particular developmental stage, stimulation of $\mathrm{GABA}_{\mathrm{A}} \mathrm{R}$ increases cytosolic $\mathrm{Ca}^{2+}$ during the day and decreases cytosolic $\mathrm{Ca}^{2+}$ during the night via an interaction with NMDA receptors and/or voltage-sensitive $\mathrm{Ca}^{2+}$ channels (Ikeda and others, 2003b). Therefore, $\mathrm{GABA}_{\mathrm{A}} \mathrm{R}$-mediated neuronal signaling may also involve cytosolic $\mathrm{Ca}^{2+}$ signaling in the regulation of the circadian clock, although further studies are needed to characterize the link between $\mathrm{GABA}_{\mathrm{A}} \mathrm{R}$ and cytosolic $\mathrm{Ca}^{2+}$ signaling.

$\mathrm{Ca}^{2+}$ influx through NMDA receptor-linked channels in SCN neurons may activate diverse downstream intracellular signaling cascades that are more closely involved in the gene transcription-translation cycles in the SCN. Light or glutamate receptor activation during early subjective night induces circadian phase delay, which is proposed to be mediated by ryanodine receptors (Ding and others 1998). Ryanodine 
receptors are known to contribute to the amplification of cytosolic $\mathrm{Ca}^{2+}$ signals via the release of $\mathrm{Ca}^{2+}$ from ryanodine-sensitive internal $\mathrm{Ca}^{2+}$ stores, called $\mathrm{Ca}^{2+}$-induced $\mathrm{Ca}^{2+}$ release (CICR). Therefore, this cascade is highly $\mathrm{Ca}^{2+}$ dependent. Rapid gene transcription of Per1 following $\mathrm{Ca}^{2+} /$ calmodulin-dependent protein kinase (CaMK) II-dependent phosphorylation of the cAMP response element binding protein (CREB) is the proposed downstream signaling pathway for the circadian phase shifts (Ginty and others 1993; Ding and others 1997; von Gall and others 1998; Yokota and others 2001). Therefore, an increase in cytosolic $\mathrm{Ca}^{2+}$ and CaMK II activation during early subjective night may be the signal that produces phase-delays in SCN neurons.

Although day-night or circadian variations in the magnitude of NMDA-induced $\mathrm{Ca}^{2+}$ responses have been proposed in SCN neurons (Colwell 2001; Pennartz and others 2001; Ikeda and others 2003b), no differences have been found in the responsiveness during the night. Consistently, CREB phosphorylation in SCN neurons is triggered by light or glutamate stimulation during both early and late subjective night (von Gall and others 1998). The response to light or glutamate, however, is opposite (i.e., delay versus advance) for stimulation during early or late subjective night. This difference may be explained in part at the level of intracellular messengers, because phase-advance due to late subjective night stimulation is insensitive to ryanodine receptor blockade but is sensitive to activation of cyclic GMP-dependent protein kinase (PKG; Prosser and others 1989; Weber and others 1995; Mathur and others 1996; Ding and others 1998; Tischkau and others 2003). PKG can be activated by nitric oxide (NO), the production of which is upregulated by NMDA-induced cytosolic $\mathrm{Ca}^{2+}$ mobilization (Garthwaite and others 1988; Knowles and others 1989; Bredt and Snyder 1989, 1990), thus, the PKG cascades may be activated as "secondary" or "indirect" signaling cascades downstream 
from glutamate-induced $\mathrm{Ca}^{2+}$ mobilization. The difference in the downstream signaling sequences followed by the cytosolic $\mathrm{Ca}^{2+}$ mobilization may produce differential clock responses depending on the particular circadian time window (for review, Gillette and Tischkau 1999; Gillette and Mitchell 2002).

\section{Technical issues in the estimation of the circadian dynamics of cytosolic $\mathrm{Ca}^{2+}$ levels in SCN neurons}

Despite the large number of reports suggesting the involvement of intracellular $\mathrm{Ca}^{2+}$ responses (i.e., receptor-mediated changes in intracellular $\mathrm{Ca}^{2+}$ concentration) in the regulation of the SCN clock, information is still limited about steady-state intracellular $\mathrm{Ca}^{2+}$ levels in SCN neurons. Whether or not the basal level of intracellular $\mathrm{Ca}^{2+}$ oscillates with a circadian profile is a fundamental question, but is technically more difficult to address.

The circadian time-dependent cytosolic $\mathrm{Ca}^{2+}$ levels in SCN cells were first estimated using fura-2 acetoxymethyl ester (AM)-based $\mathrm{Ca}^{2+}$ imaging in acute hypothalamic slices from rats, and the population mean cytosolic $\mathrm{Ca}^{2+}$ in SCN cells was found to be higher during the day than during the night (Colwell 2000). It was proposed that action potentials and voltage-gated $\mathrm{Ca}^{2+}$ channel activation drive the circadian variations in cytosolic $\mathrm{Ca}^{2+}$ levels because the day-night or circadian difference in cytosolic $\mathrm{Ca}^{2+}$ was blocked by the voltage-gated $\mathrm{Na}^{+}$-channel blocker tetrodotoxin (TTX) and the voltage-sensitive $\mathrm{Ca}^{2+}$-channel blocker methoxyverapamil (Colwell 2000). Using a similar experimental strategy, however, our group observed neither the day-night difference in the population mean cytosolic $\mathrm{Ca}^{2+}$ nor the effect of TTX on the cytosolic $\mathrm{Ca}^{2+}$ levels in SCN cells (Ikeda and others 2003b). In contrast, 
we observed significant effects of extracellular $\mathrm{Mg}^{2+}$ on baseline cytosolic $\mathrm{Ca}^{2+}$ levels both during the day and night (Ikeda and others 2003b). We observed later, however, that the effect of $\mathrm{Mg}^{2+}$ was caused by the differential dissociate constant of fura- 2 to $\mathrm{Ca}^{2+}$ in the presence or absence of $\mathrm{Mg}^{2+}$, not physiological processes (Ikeda, unpublished data). Both of these $\mathrm{Ca}^{2+}$ imaging experiments involved staining hypothalamic slices with membrane permeable fura-2 AM, which does not distinguish neuronal and glial $\mathrm{Ca}^{2+}$ responses (Colwell 2000; Ikeda and others 2003b). In addition, both of these studies compared different SCN cells sampled in different slices during either the day or night, because fura- 2 can not be used to follow cytosolic $\mathrm{Ca}^{2+}$ of single cells over a complete circadian cycle. Therefore, a part of the controversy may be due to these experimental difficulties.

More fundamental and theoretical problems, however, may underlie the analysis of steady-state cytosolic $\mathrm{Ca}^{2+}$ levels using conventional $\mathrm{Ca}^{2+}$ imaging techniques. In general, high-affinity $\mathrm{Ca}^{2+}$ dyes, such as fura-2 $\left(K_{d}=135 \mathrm{nM}\right.$ in $\mathrm{Mg}^{2+}$-free buffer and $K_{d}$ $=224 \mathrm{nM}$ in $1 \mathrm{mM} \mathrm{Mg}^{2+}$ buffer), if the cells are thoroughly loaded (bath application at 3-10 mM), may reduce the baseline cytosolic $\mathrm{Ca}^{2+}$ levels because their affinity range is similar to that of the commonly used $\mathrm{Ca}^{2+}$ chelator BAPTA $\left(K_{d}=160 \mathrm{nM}\right.$ in $\mathrm{Mg}^{2+}$-free buffer and $K_{d}=700 \mathrm{nM}$ in $1 \mathrm{mM} \mathrm{Mg}^{2+}$ buffer) and is higher than the physiological baseline cytosolic $\mathrm{Ca}^{2+}$ concentration. Reduction of the dye concentration and observation of dimmer cells with a more sensitive imaging setup may increase the accuracy of the estimated baseline $\mathrm{Ca}^{2+}$ levels, but such precise control of intracellular dye concentrations is theoretically difficult due to the unknown dye-leakage rate from the cells and dye-uptake rate into the organelles. Alternatively, use of low-affinity $\mathrm{Ca}^{2+}$ dyes, such as BTC $\left(K_{d}=7 \mu \mathrm{M}\right)$, may reduce the $\mathrm{Ca}^{2+}$ chelating artifacts, but these 
dyes are not sensitive enough to be used for detection of nanomolar levels of cytosolic $\mathrm{Ca}^{2+}$. Therefore, conventional $\mathrm{Ca}^{2+}$ dyes may not be useful in the estimation of the steady-state levels of $\mathrm{Ca}^{2+}$ in SCN neurons.

Nevertheless, circadian rhythmic changes in cytosolic $\mathrm{Ca}^{2+}$ have been successfully observed in tobacco and Arabidopsis plants (Johnson and others 1995; Wood and others 2001) using the $\mathrm{Ca}^{2+}$-sensing protein sensor aequorin. Aequorin is a jellyfish protein used to detect a wide range of cytosolic $\mathrm{Ca}^{2+}$ concentrations $(0.1-100 \mu \mathrm{M})$ via its chemi-luminescence. Aequorin is not exported, secreted, compartmentalized, nor sequestered within cells, and is thus suitable for the long-term measurement of cytosolic $\mathrm{Ca}^{2+}$. Also, photon-counting analysis of aequorin chemi-luminescence enables cytosolic $\mathrm{Ca}^{2+}$ measurement using a smaller number of sensor molecules and may avoid $\mathrm{Ca}^{2+}$ chelating problems such as those described with conventional dye imaging. Despite the advantageous characteristics of aequorin for the long-term monitoring of cytosolic $\mathrm{Ca}^{2+}$ in tobacco and Arabidopsis seedlings (millimeter to centimeter in length), it has not been successfully used in SCN neurons (the cell body is less than $10 \mu \mathrm{m}$ diameter), presumably due to the limited spatial resolution of chemi-luminescence signals.

To examine progressive changes in free $\mathrm{Ca}^{2+}$ concentration in single SCN neurons over multiple circadian cycles, our group used the $\mathrm{Ca}^{2+}$-sensitive fluorescent protein cameleon (Miyawaki and others 1997, 1999). The cameleon used (YC2.1) was constructed with cyan-shifted and yellow-shifted green fluorescent proteins linked to opposite ends of the $\mathrm{Ca}^{2+}$ binding region of calmodulin. Cytosolic $\mathrm{Ca}^{2+}$ levels are estimated from the reciprocal emission intensity changes at $480 \mathrm{~nm}$ and $535 \mathrm{~nm}$ (i.e., F535 nm/F480 nm ratio) produced by the fluorescent resonance energy transfer (FRET) 
in the $\mathrm{Ca}^{2+}$-bound cameleon molecule. Although the primary dissociation constant of YC2.1 $\left(K_{d 1}=100 \mathrm{nM}\right)$ is higher than that of fura-2, a single YC2.1 molecule is much brighter. This enables the visualization of single neurons using a smaller number of sensor molecules, and may avoid $\mathrm{Ca}^{2+}$ chelating artifacts. YC2.1 has been successfully used in primary cultures of hippocampal and cortical neurons (Miyawaki and others 1999; Tsuchiya and others 2002). Also, YC2.1 has been stably expressed in C. elegans neurons (Kerr and others 2000), demonstrating its applicability for long-term monitoring of neuronal cytosolic $\mathrm{Ca}^{2+}$. Using SCN slice cultures transfected with YC2.1 cDNA linking to a neuron-specific enolase promoter (Sakimura and others 1995), our group finally succeeded in the continuous monitoring of steady-state cytosolic $\mathrm{Ca}^{2+}$ levels in single SCN neurons over entire circadian periods (Ikeda and others 2003a: Fig. 2).

\section{Circadian rhythms in cytosolic calcium concentration in SCN neurons: what the message tells us.}

Circadian rhythms are observed in cytosolic $\mathrm{Ca}^{2+}$ concentration in approximately two thirds (64\%) of the population of cultured SCN neurons with a trough at approximately $120 \mathrm{nM}$ and peak at approximately $440 \mathrm{nM}$ (Ikeda and others 2003a). The circadian periods are generally synchronized among cells in the organotypic culture, but the phases are slightly advanced or delayed (Fig. 2). The average peak in $\mathrm{Ca}^{2+}$ is 4-5 hours before the peak in action potential firing, recorded simultaneously using a multiple-electrode-array dish. The circadian cytosolic $\mathrm{Ca}^{2+}$ rhythm is specific to SCN neurons because neurons and glial cells located outside of the SCN exhibit no changes in cytosolic $\mathrm{Ca}^{2+}$ levels. The circadian cytosolic $\mathrm{Ca}^{2+}$ rhythm is driven by the release 
of $\mathrm{Ca}^{2+}$ from ryanodine-sensitive $\mathrm{Ca}^{2+}$ stores because ryanodine and 8-bromo-cyclic ADP ribose significantly damp the cytosolic $\mathrm{Ca}^{2+}$ rhythm. Inositol $(1,4,5)$-trisphosphate $\left(\mathrm{IP}_{3}\right)$-sensitive $\mathrm{Ca}^{2+}$ stores are present in SCN neurons (Kopp and others 1999; Ikeda and others 2000), but the contribution of this $\mathrm{Ca}^{2+}$ store in the generation of the circadian cytosolic $\mathrm{Ca}^{2+}$ rhythm appears to be small, because the $\mathrm{Ca}^{2+}$-ATPase inhibitor, thapsigargin, has little effect on the circadian cytosolic $\mathrm{Ca}^{2+}$ rhythm. The circadian cytosolic $\mathrm{Ca}^{2+}$ rhythm is also resistant to TTX, which blocks action potential firing in SCN neurons. Moreover, the circadian cytosolic $\mathrm{Ca}^{2+}$ rhythm is resistant to nimodipine, which blocks L-type $\mathrm{Ca}^{2+}$ channels and is reported to reduce action potential firing in SCN neurons (Pennartz and others 2002). These findings suggest that $\mathrm{Ca}^{2+}$ influx through the plasma membrane is not the primary mechanism underlying the generation of the circadian cytosolic $\mathrm{Ca}^{2+}$ rhythm.

The observation that the circadian cytosolic $\mathrm{Ca}^{2+}$ rhythm is TTX-resistant raises the possibility that some of the clock genes regulate the circadian cytosolic $\mathrm{Ca}^{2+}$ rhythm (Fig. 3A). Therefore, screening of gene function in this regard is a critical next step toward a more complete understanding of the mechanisms underlying the circadian clock. An important aspect to remember in this process of discovery, is that for many genes, the converse will be true; the $\mathrm{Ca}^{2+}$ rhythms regulate the gene transcription cycles, because cytosolic $\mathrm{Ca}^{2+}$ is a transcriptional regulator for numerous genes. Using DNA microarrays, not only the known clock genes but also hundreds of other genes have been shown to oscillate with a circadian profile in the SCN (Panda and others 2002b; Ueda and others 2002; for review, Delaunay and Laudet 2002). It is unlikely that all these genes oscillate by their transcription-translation feedback loops. Rather, it is more plausible that many of these gene transcription rhythms are driven by the circadian 
cytosolic $\mathrm{Ca}^{2+}$ rhythm (Fig. 3B).

Consequently, this raises the specific question as to whether the known clock gene oscillations are under the influence of circadian cytosolic $\mathrm{Ca}^{2+}$ rhythms or vice versa. As described above, glutamate-induced $\mathrm{Ca}^{2+}$ influx together with ryanodine-receptor mediated amplification of $\mathrm{Ca}^{2+}$ signals and resultant CREB phosphorylation by CaMKII have been proposed to be the primary signaling pathway for resetting the clock gene (Ginty and others 1993; Ding and others 1997, 1998; von Gall and others 1998; Yamaguchi and others 2000; Yokota and others 2001). Despite the evidence for cytosolic $\mathrm{Ca}^{2+}$-mediated control of clock gene transcription, the current model explaining the core circadian oscillations is based primarily on the feedback regulations of clock gene transcriptions by their own translational products with reciprocal interactions of different clock gene products (Shearman and others 2000; Reppert and Weaver 2002). The model is reasonable because the core SCN oscillation was proposed to be TTX-resistant (Schwartz and others 1987) and the circadian rhythms in cytosolic $\mathrm{Ca}^{2+}$ estimated in acute SCN slices using conventional fura-2 imaging were proposed to be TTX-dependent (Colwell 2000). Based on these earlier data, the involvement of TTX-sensitive $\mathrm{Ca}^{2+}$ levels in the regulation of the core circadian loop would be ruled out. Nevertheless, based on the recent demonstration of a TTX-resistant circadian cytosolic $\mathrm{Ca}^{2+}$ rhythm in cultured SCN neurons (Ikeda and others 2003a), and the fact that this rhythm is driven by the $\mathrm{Ca}^{2+}$ release from ryanodine-sensitive internal $\mathrm{Ca}^{2+}$ stores (i.e., the same machinery that activates Per1 transcription following glutamate stimulation) and phase-advanced to the luciferase-reported circadian rhythms of Per1 transcriptions (Yamaguchi and others 2001), it is likely that circadian oscillations in at least one known clock gene are under 
the strong influence of circadian cytosolic $\mathrm{Ca}^{2+}$ rhythms.

\section{Sedative nuclear $\mathrm{Ca}^{2+}$ levels in SCN neurons: a characteristic common to all clock cells?}

One of the advantages of protein sensor-based $\mathrm{Ca}^{2+}$ imaging is that the sensor can be designed to travel into specific organelles by fusion of the sensor protein to organelle-transferring proteins. Using nucleus-targeted cameleon, nuclear $\mathrm{Ca}^{2+}$ dynamics were studied in SCN neurons (Ikeda and others 2003a). We found that nuclear $\mathrm{Ca}^{2+}$ is mobilized as well as cytosolic $\mathrm{Ca}^{2+}$ after pharmacological stimulation of NMDA receptors in SCN neurons, suggesting that the nuclear targeted YC2.1 is functional in SCN neurons. There is no evidence, however, of circadian rhythms in nuclear $\mathrm{Ca}^{2+}$ concentration. The nuclear $\mathrm{Ca}^{2+}$ concentration is steady at approximately $35 \mathrm{nM}$, suggesting a sedative nature of nuclear $\mathrm{Ca}^{2+}$ in SCN neurons. In general, nuclear $\mathrm{Ca}^{2+}$ levels have been described to parallel cytosolic $\mathrm{Ca}^{2+}$ levels, due to $\mathrm{Ca}^{2+}$ permeable pores and an absence of an active $\mathrm{Ca}^{2+}$ transport system on the nuclear membrane (Brini and others 1993, 1994). The compartmentalization of cytosolic and nuclear $\mathrm{Ca}^{2+}$ has been described in several cell types, however. For example, using nucleus-targeted and untargeted aequorin, Badminton and others (1995) demonstrated a

smaller $\mathrm{Ca}^{2+}$ response in the nucleus than that in the cytosol of COS7 cells, suggesting “theoretical” nuclear $\mathrm{Ca}^{2+}$ barriers.

One possible mechanism underlying the reduced nuclear $\mathrm{Ca}^{2+}$ levels in SCN neurons may be $\mathrm{Ca}^{2+}$ buffering proteins, such as calbindin-D28k (CB) and calretinin (CR), that are expressed on SCN neurons in a species-specific manner (Silver and others 1996b, 1999; Mahoney and others 2000). The hypothalamic cultures used for 
the cameleon $\mathrm{Ca}^{2+}$ imaging experiments had significant levels of $\mathrm{CB}$ and $\mathrm{CR}$ expression in the SCN (Ikeda and Allen 2003; Ikeda and others 2003a). Both of these $\mathrm{Ca}^{2+}$-binding proteins have high affinity for $\mathrm{Ca}^{2+}\left(\mathrm{K}_{\mathrm{d}}=300 \mathrm{nM}\right.$ for $\mathrm{CB}$ and $250 \mathrm{nM}$ for CR; Cheung and others 1993) close to the range of circadian cytosolic $\mathrm{Ca}^{2+}$ variations in SCN neurons. The molecular sizes of CB and CR are small enough to distribute in the nucleus as well as in the cytosol in SCN neurons. Therefore, these $\mathrm{Ca}^{2+}$-binding proteins may buffer both cytosolic and nuclear $\mathrm{Ca}^{2+}$. More importantly, CB may not be evenly distributed inside the SCN neurons throughout the circadian cycles, because the number of nuclear CB-positive SCN neurons is greater during the subjective day than during the subjective night (Hamada and others 2003). Thus, it is likely that a $\mathrm{Ca}^{2+}$-buffering system may contribute to the circadian dynamics of cytosolic $\mathrm{Ca}^{2+}$ concentrations and/or stabilization of nuclear $\mathrm{Ca}^{2+}$ levels in SCN neurons. A high-capacity $\mathrm{Ca}^{2+}$-buffering system in SCN neurons may prevent undesirable phase shifts via general levels of neuronal excitation and contribute to the stabilization of circadian oscillations.

The intracellular $\mathrm{Ca}^{2+}$ dynamics described in tobacco seedlings by Wood and others (2001) are similar to the intracellular $\mathrm{Ca}^{2+}$ dynamics in SCN neurons; there are circadian rhythms in cytosolic $\mathrm{Ca}^{2+}$, but not in nuclear $\mathrm{Ca}^{2+}$ concentration. Although $\mathrm{Ca}^{2+}$ homeostasis in plant cells is different from that in mammalian cells, the presence of circadian rhythms in cytosolic $\mathrm{Ca}^{2+}$ and a stable nuclear $\mathrm{Ca}^{2+}$ concentration across circadian cycles may be a common characteristic for a wide variety of cells with a critical role in circadian clock regulation. 
Acknowledgements-This work was supported in part by a grant-in-aid for scientific research (B14380372) by the Ministry of Education, Culture, Sports, Science, and Technology Japan to M.I. 


\section{References}

Allen CN, Jiang ZG, Teshima K, Darland T, Ikeda M, Nelson CS, Quigley DI, Yoshioka T, Allen RG, Rea MA, and Grandy DK. 1999. Orphanin-FQ/nociceptin (OFQ/N) modulates the activity of suprachiasmatic nucleus neurons. J Neurosci 19:2152-60.

Antoch MP, Song EJ, Chang AM, Vitaterna MH, Zhao Y, Wilsbacher LD, Sangoram AM, King DP, Pinto LH, and Takahashi JS. 1997. Functional identification of the mouse circadian clock gene by transgenic BAC rescue. Cell 89:655-67.

Aston-Jones G, Chen S, Zhu Y, and Oshinsky ML. 2001. A neural circuit for circadian regulation of arousal. Nat Neurosci 4:732-8.

Badminton MN, Kendall JM, Sala-Newby G, and Campbell AK. 1995. Nucleoplasmin-targeted aequorin provides evidence for nucleus calcium barrier. Exp Cell Res 216:236-43.

Berson DM, Dunn FA, and Takao M. 2002. Phototransduction by retinal ganglion cells that set the circadian clock. Science 295:1070-3.

Bredt DS and Snyder SH 1989. Nitric oxide mediates glutamate-linked enhancement of cGMP levels in the cerebellum. Proc Natl Acad Sci USA 86:9030-3.

Bredt DS and Snyder SH 1990. Isolation of nitric oxide synthetase, a calmodulin-requiring enzyme. Proc Natl Acad Sci USA 87:682-5.

Brini M, Murgia M, Pasti L, Picard D, Pozzan T, and Rizzuto R. 1993. Nuclear Ca ${ }^{2+}$ concentration measured with specifically targeted recombinant aequorin. EMBO J $12: 4813-9$.

Brini M, Marsault R, Bastianutto C, Pozzan T, and Rizzuto R. 1994. Nuclear targeting of aequorin. A new approach for measuring nuclear $\mathrm{Ca}^{2+}$ concentration in intact 
cells. Cell Calcium 16:259-68.

Buijs RM, Hou YX, Shin S, and Renaud LP. 1994. Ultrastructural evidence from intraand extranuclear projections of GABAergic neurons of the suprachiasmatic nucleus. J Comp Neurol 340:381-391.

Cahill GM and Menaker M. 1989a. Responses of the suprachiasmatic nucleus to retinohypothalamic tract volleys in a slice preparation of the mouse hypothalamus. Brain Res 479:65-75.

Cahill GM and Menaker M. 1989b. Effects of excitatory amino acid receptor antagonists and agonists on suprachiasmatic nucleus responses to retinohypothalamic tract volleys. Brain Res 479:76-82.

Cheung WT, Richards DE, and Rogers JH. 1993. Calcium binding by chick calretinin and rat calbindin D28k synthesised in bacteria. Eur J Biochem 215:401-10.

Colwell CS. 2000. Circadian modulation of calcium levels in cells in the suprachiasmatic nucleus. Eu J Neurosci 12: 571-6.

Colwell CS. 2001. NMDA-evoked calcium transients and currents in the suprachiasmatic nucleus: gating by the circadian system. Eur J Neurosci $13: 1420-8$

Decavel C and van den Pol AN. 1990. GABA: a dominant neurotransmitter in the hypothalamus. J Comp Neurol 302:1019-37.

Delaunay F and Laudet V. 2002. Circadian clock and microarrays: mammalian genome gets rhythm. Trends Genet 18:595-7.

de Vries MJ, Cardozo BN, van der Want J, de Wolf A, and Meijer JH 1993. Glutamate immunoreactivity in terminals of the retinohypothalamic tract of the brown Norwegian rat. Brain Res 612:231-7. 
Ding JM, Chen D, Iber ET, Faiman LE, Rea MA, and Gillette MA. 1994. Resetting the biological clock: mediation of nocturnal circadian shifts by glutamate and no. Science 266:1713-7.

Ding JM, Faiman LE, Hurst WJ, Kuriashkina LR, and Gillette MA. 1997. Resetting the biological clock: mediation of nocturnal CREB phosphorylation via light, glutamate, and nitric oxide. J Neurosci 17: 667-75.

Ding JM, Buchanan GF, Tischkau SA, Chen D, Kuriashkina L, Faiman LE, Alster JM, McPherson PS, Campbell KP, and Gillette MU. 1998. A neuronal ryanodine receptor mediates light-induced phase delays of the circadian clock. Nature 394:381-4.

Earnest DJ and Sladek CD. 1986. Circadian rhythms of vasopressin release from individual rat suprachiasmatic explants in vitro. Brain Res 382:129-33.

Edelstein K and Amir S. 1999. The role of the intergeniculate leaflet in entrainment of circadian rhythms to skeleton photoperiod. J Neurosci 19:372-80.

Flett J and Colwell CS. 1999. Serotonin modulation of calcium transients in cells in the suprachiasmatic nucleus. J Biol Rhythms 14:354-63.

Gannon RL and Rea MA. 1994. In situ hybridization of antisense mRNA oligonucleotides for AMPA, NMDA and metabotropic glutamate receptor subtypes in the rat suprachiasmatic nucleus at different phases of the circadian cycle. Mol Brain Res 23:338-44.

Garthwaite J, Charles SL, and Chess-Williams R 1988. Endothelium-derived relaxing factor release on activation of NMDA receptors suggests role as intercellular messenger in the brain. Nature 336:385-8.

Gillette MU and Tischkau SA. 1999. Suprachiasmatic nucleus: the brain's circadian 
clock. Recent Prog Horm Res 54:33-58.

Gillette MU and Mitchell JW. 2002. Signaling in the suprachiasmatic nucleus: selectively responsive and integrative. Cell Tissue Res 309:99-107.

Ginty DD, Kornhauser JM, Thompson MA, Banding H, Mayo KE, Takahashi JS, and Greenberg ME. 1993. Regulation of CREB phosphorylation in the suprachiasmatic nucleus by light and a circadian clock. Science 260:238-241.

Gooley JJ, Lu J, Chou TC, Scammell TE, and Saper CB. 2001. Melanopsin in cells of origin of the retinohypothalamic tract. Nat Neurosci 4:1165.

Goto K, Laval-Martin DL, and Edmunds LN. 1985. Biochemical modeling of an autonomously oscillatory circadian clock in Euglena. Science 228:1284-8.

Green DJ and Gillette R. 1982. Circadian rhythm of firing rate recorded from single cells in the rat suprachiasmatic brain slice. Brain Res 245:198-200.

Hamada T, LeSauter J, Lokshin M, Romero M-T, Yan L, Venuti JM, and Silver R. 2003. Calbindin influences response to photic input in suprachiasmatic nucleus. J Neurosci 23: 8820-6.

Hannibal J, Ding JM, Chen D, Fahrenkrug J, Larsen PJ, Gillette MU, and Mikkelsen JD. 1997. Pituitary adenylate cyclase-activating peptide (PACAP) in the retinohypothalamic tract: a potential daytime regulator of the biological clock. $\mathrm{J}$ Neurosci 17:2637-44.

Hannibal J. 2002. Neurotransmitters of the retino-hypothalamic tract. Cell Tissue Res 309:73-88.

Harrington ME, Nance DM, and Rusak B. 1987. Double-labeling of neuropeptide Y-immunoreactive neurons which project from the geniculate to the suprachiasmatic nuclei. Brain Res 410:275-282. 
Harrington ME and Rusak B. 1989. Photic response of geniculo-hypothalamic tract neurons in the Syrian hamster. Vis Neurosci 2:367-75.

Hasegawa K, Kikuchi H, Ishizaki S, Tamura A, Tsukahara Y, Nakaoka Y, Iwai E, and Sato T. 1999. Simple fluctuation of $\mathrm{Ca}^{2+}$ elicits the complex circadian dynamics of cyclic AMP and cyclic GMP in Paramecium. J Cell Sci 112:201-7.

Hattar S, Liao HW, Takao M, Berson DM, and Yau KW. 2002. Melanopsin-containing retinal ganglion cells: architecture, projections, and intrinsic photosensitivity. Science 295:1065-70.

Honma S, Ikeda M, Abe H, Tanahashi Y, Namihira M, Honma K, and Nomura M. 1998. Circadian oscillation of BMAL1, a partner of a mammalian clock gene Clock, in rat suprachiasmatic nucleus. Biochem Biophys Res Commun 250:83-7.

Honma S, Kawamoto T, Takagi Y, Fujimoto K, Sato F, Noshiro M, Kato Y, and Honma K. 2002. Dec1 and Dec2 are regulators of the mammalian molecular clock. Nature 419:841-4.

Honma S and Honma K. 2003. Biological clock; Calcium links pendulum to hands. Trends Neurosci in press.

Ikeda M, Sugiyama T, Suzuki K, Moriya T, Shibata S, Katsuki M, Allen CN, and Yoshioka T 2000. PLC- $\beta 4$-independent $\mathrm{Ca}^{2+}$ rise via muscarinic receptors in the mouse suprachiasmatic nucleus. Neuroreport 11:907-12.

Ikeda M and Allen CN. 2003. Developmental changes in calbindin-D28k and calretinin immunoreactive neurons in the suprachiasmatic nucleus. Eu J Neurosci 17:1111-8.

Ikeda M, Sugiyama T, Wallace CS, Gompf HS, Yoshioka T, Miyawaki A, and Allen CN. 2003a. Circadian dynamics of cytosolic and nuclear $\mathrm{Ca}^{2+}$ in single suprachiasmatic nucleus neurons. Neuron 38:253-63. 
Ikeda M, Yoshioka T, and Allen CN. 2003b. Developmental and circadian changes in $\mathrm{Ca}^{2+}$ mobilization mediated by $\mathrm{GABA}_{\mathrm{A}}$ and NMDA receptors in the suprachiasmatic nucleus. Eu J Neurosci 17:58-70.

Inouye ST and Kawamura H. 1979. Persistence of circadian rhythmicity in a mammalian hypothalamic 'island' containing the suprachiasmatic nucleus. Proc Natl Acad Sci USA 76: 5962-6.

Jiang ZG, Yang YQ, Liu ZP, and Allen CN. 1997. Membrane properties and synaptic inputs of the suprachiasmatic nucleus neurons in rat brain slices. J Physiol (Lond) 499:141-59.

Jiang ZG, Teshima K, Yang Y, Yoshioka T, and Allen CN. 2000. Pre- and postsynaptic actions of serotonin on rat suprachiasmatic nucleus neurons. Brain Res 866:247-56.

Jin X, Shearman LP, Weaver DR, Zylka MJ, de Vries GJ, and Reppert SM. 1999. A molecular mechanism regulating rhythmic output from the suprachiasmatic circadian clock. Cell 96:57-68.

Johnson CH, Knight MR, Kondo T, Masson P, Sedbrook J, Haley A, and Trewavas A. 1995. Circadian oscillation of cytosolic and chloroplastic free calcium in plants. Science 269:1863-5.

Kerr R, Lev-Ram V, Baird G, Vincent P, Tsien RY, and Schafer WR. 2000. Optical imaging of calcium transients in neurons and pharyngeal muscle of C. elegans. Neuron 26: 583-94.

King DP, Zhao Y, Sangoram AM, Wilsbacher LD, Tanaka M, Antoch MP, Steeves TD, Vitaterna MH, Kornhauser JM, Lowrey PL, Turek FW, and Takahashi JS. 1997. Positional cloning of the mouse circadian clock gene. Cell 89:641-53. 
Knowles RG, Palacios M, Palmer RM, and Moncada S. 1989. Formation of nitric oxide from L-arginine in the central nervous system: a transduction mechanism for stimulation of the soluble guanylate cyclase. Proc Natl Acad Sci USA 86:5159-62.

Kondo T and Ishiura M. 1999. The circadian clocks of plants and cyanobacteria. Trends Plant Sci 4:171-6.

Kopp MD, Schomerus C, Dehghani F, Korf HW, and Meissl H. 1999. Pituitary adenylate cyclase-activating polypeptide and melatonin in the suprachiasmatic nucleus: effects on the calcium signal transduction cascade. J Neurosci 19: 206-19.

Kume K, Zylka MJ, Sriam S, Shearman LP, Weaver DR, Jin X, Maywood ES, Hasting MH, and Reppert SM. 1999. mCRY1 and mCRY2 are essential components of the negative limb of the circadian clock feedback loop. Cell 98:193-205.

Liu C and Reppert SM. 2000. GABA synchronizes clock cells within the suprachiasmatic circadian clock. Neuron 25:123-8.

Mahoney MM, Nunez AA, and Smale L. 2000. Calbindin and Fos within the suprachiasmatic nucleus and the adjacent hypothalamus of Arvicanthis Niloticus and Rattus Norvegicus. Neuroscience 99:565-75.

Mathur A, Golombek DA, and Ralph MR. 1996. cGMP-dependent protein kinase inhibitors block light-induced phase advances of circadian rhythms in vivo. Am J Physiol 270:R1031-6.

Michel S, Itri J, and Colwell CS. 2002. Excitatory mechanisms in the suprachiasmatic nucleus: the role of AMPA/KA glutamate receptors. J Neurophysiol 88:817-28.

Miyawaki A, Llopis J, Heim R, McCaffery JM, Adams JA, Ikura M, and Tsien RY. 1997. Fluorescent indicators for $\mathrm{Ca}^{2+}$ based on green fluorescent proteins and 
calmodulin. Nature 388:882-7.

Miyawaki A, Griesbeck O, Heim R, and Tsien RY. 1999. Dynamic and quantitative $\mathrm{Ca}^{2+}$ measurements using improved cameleons. Proc Natl Acad Sci USA 96:2135-40.

Moore RY and Eichler VB. 1972. Loss of a circadian adrenal corticosterone rhythm following suprachiasmatic lesions in the rat. Brain Res 42:201-6.

Moore RY and Speh JC. 1993. GABA is the principal neurotransmitter of the circadian system. Neurosci Lett 150:112-6.

Moriya T, Ikeda M, Teshima K, Hara R, Kuriyama K, Yoshioka T, Allen CN, and $\begin{array}{llll}\text { Shibata } & \text { S. } & \text { 2003. } & \text { Facilitation }\end{array}$ alpha-amino-3-hydroxy-5-methylisoxazole-4-propionate receptor transmission in the suprachiasmatic nucleus by aniracetam enhances photic responses of the biological clock in rodents. J Neurochem 85:978-87.

Okamura H, Berod A, Julien JF, Geffard M, Kitahama K, Mallet J, and Bobliller P. 1986. Demonstration of GABAergic cell bodies in the suprachiasmatic nucleus: in situ hybridization of glutamic acid decarboxylase (GAD) mRNA and immunocytochemistry of GAD and GABA. Neurosci Lett 102:131-6.

Panda S, Hogenesch JB, and Kay SA. 2002a. Circadian rhythms from flies to human. Nature 417:329-35.

Panda S, Antoch MP, Miller BH, Su AI, Schook AB, Straume M, Schultz PG, Kay SA, Takahashi JS, and Hogenesch JB. 2002b. Coordinated transcription of key pathways in the mouse by the circadian clock. Cell 109:307-20.

Pennartz CM, Hamstra R, and Geurtsen AM. 2001. Enhanced NMDA receptor activity in retinal inputs to the rat suprachiasmatic nucleus during the subjective night. $\mathrm{J}$ Physiol (Lond) 532:181-94. 
Pennartz CM, de Jeu MT, Bos NP, Schaap J, and Geurtsen AM. 2002. Diurnal modulation of pacemaker potentials and calcium current in the mammalian circadian clock. Nature 416:286-90.

Perez de la Mora M, Possani LD, Tapia R, Teran L, Palacios R, Fuxe K, Hokfelt T, and Ljungdhal A. 1981. Demonstration of gamma-aminobutyrate-containing nerve terminals by means of antibodies against glutamate decarboxylase. Neuroscience 6:875-95.

Pickard GE, Weber ET, Scott PA, Riberdy AF, and Rea MA. 1996. 5HT1B receptor agonists inhibit light-induced phase shifts of behavioral circadian rhythms and expression of the immediate-early gene c-fos in the suprachiasmatic nucleus. $\mathrm{J}$ Neurosci 16:8208-20.

Pickard GE, Smith BN, Belenky M, Rea MA, Dudek FE, and Sollars PJ. 1999. 5-HT1B receptor-mediated presynaptic inhibition of retinal input to the suprachiasmatic nucleus. J Neurosci 19:4034-45.

Prosser RA, McArthur AJ, and Gillette MU. 1989. cGMP induces phase shifts of a mammalian circadian pacemaker at night, in antiphase to cAMP effects. Proc Natl Acad Sci USA 86:6812-5.

Provencio I, Rollag MD, and Castrucci AM. 2002. Photoreceptive net in the mammalian retina. This mesh of cells explains how some blind mice can still tell day from night. Nature 415:493.

Quintero JE and McMahon DG. 1999. Serotonin modulates glutamate responses in isolated suprachiasmatic nucleus neurons. J Neurophysiol 82:533-9.

Rea MA. 1998. Photic entrainment of circadian rhythms in rodents. Chronobiol Int 15:395-423. 
Reppert SM and Weaver DR. 2002. Coordination of circadian timing in mammals. Nature 418: 935-41.

Rusak B and Zucker I. 1979. Neuronal regulation of circadian rhythms. Physiol Rev 59:449-526.

Sakimura K, Kushiya E, Ogura A, Kudo Y, Katagiri T, and Takahashi Y. 1995. Upstream and intron regulatory regions for expression of the rat neuron-specific enolase gene. Mol Brain Res 28:19-28.

Sangoram AM, Saez L, Antoch MP, Gekakis N, Staknis D, Whiteley A, Fruechte EM, Vitaterna MH, Shimomura K, King DP, Young MW, Weitz CJ, and Takahashi JS. 1998. Mammalian circadian autoregulatory loop: a timeless ortholog and mPer1 interact and negatively regulate CLOCK-BMAL1-induced transcription. Neuron 21:1101-13.

Schurov IL, McNulty S, Best JD, Sloper PJ, and Hastings MH. 1999. Glutamatergic induction of CREB phosphorylation and Fos expression in primary cultures of the suprachiasmatic hypothalamus in vitro is mediated by co-ordinate activity of NMDA and non-NMDA receptors. J Neuroendocrinol 11:43-51.

Schwartz WJ, Gross RA, and Morton MT. 1987. The suprachiasmatic nuclei contain a tetrodotoxin-resistant circadian pacemaker. Proc Natl Acad Sci USA 84:1694-8.

Shearman LP, Sriam S, Weaver DR, Maywood ES, Chaves I, Zheng B, Kume K, Lee CC, van der Horst GT, Hastings MH, and Reppert SM. 2000. Interacting molecular loops in the mammalian circadian clock. Science 288:1013-9.

Shinohara K, Honma S, Katsuno Y, Katsuno Y, Abe H, and Honma K. 1995. Two distinct oscillators in the rat suprachiasmatic nucleus. Proc Natl Acad Sci USA 92:7396-400. 
Silver R, LeSauter J, Tresco PA, and Lehman MN. 1996a. A diffusible coupling signal from the transplanted suprachiasmatic nucleus controlling circadian locomotor rhythms. Nature 382:810-3.

Silver R, Romero MT, Besmer HR, Leak R, Nunez JM, and LeSauter J. 1996b. Calbindin-D28k cells in the hamster SCN express light-induced Fos. Neuroreport 7:1224-8.

Silver R, Sookhoo AI, LeSauter J, Stevens P, Jansen HT, and Lehman MN. 1999. Multiple regulatory elements result in regional specificity in circadian rhythms of neuropeptide. Neuroreport 10:3165-74.

Smith BN, Sollars PJ, Dudek FE, and Pickard GE. 2001. Serotonergic modulation of retinal input to the mouse suprachiasmatic nucleus mediated by 5-HT1B and 5-HT7 receptors. J Biol Rhythms 16:25-38.

Stephan FK and Zucker I. 1972. Circadian rhythms in drinking behavior and locomotor activity of rats are eliminated by hypothalamic lesions. Proc Natl Acad Sci USA 69:1583-6.

Takeuchi Y, Takeshima M, Katoh Y, Nishikawa T, and Takahashi K. 1991. N-methyl-D-aspartate, quisqualate and kainite receptors are all involved in transmission of photic stimulation in the suprachiasmatic nucleus in rats. Brain Res 563:127-31.

Tei H, Okamura H, Shigeyoshi Y, Fukuhara C, Ozawa R, Hirose M, and Sakaki Y. 1997. Circadian oscillation of a mammalian homologue of the Drosophila period gene. Nature 389:512-6.

Tischkau SA, Weber ET, Abbott SM, Mitchell JW, and Gillette MU. 2003. Circadian clock-controlled regulation of cGMP-protein kinase G in the nocturnal domain. $\mathrm{J}$ 
Neurosci 23:7543-50.

Tsuchiya R, Yoshiki F, Kudo Y, and Morita M. 2002. Cell type-selective expression of green fluorescent protein and calcium indicating protein, yellow cameleon, in rat cortical primary cultures. Brain Res 956: 221-9.

Ueda HR, Chen W, Adachi A, Wakamatsu H, Hayashi S, Takasugi T, Nagano M, Nakahama K, Suzuki Y, Sugano S, Iino M, Shigeyoshi Y, and Hashimoto S. 2002. A transcription factor response element for gene expression during circadian night. Nature 418:534-9.

van der Horst GT, Muijtjens M, Kobayashi K, Takano R, Kanno S, Takao M, de Wit J, Verkerk A, Eker AP, van Leenen D, Buijs R, Bootsma D, Hoeijmakers JH, and Yasui A. 1999. Mammalian Cry1 and Cry2 are essential for maintenance of circadian rhythms. Nature 398:627-30.

von Gall C, Durffield GE, Hastings MH, Kopp, MD, Dehghani F, Korf HW, and Stehle JH. 1998. CREB in the mouse SCN: a molecular interface coding the phase-adjusting stimuli light, glutamate, PACAP, and melatonin for clockwork access. J Neurosci 18:10389-97.

Wagner S, Castel M, Gainer H, and Yarom Y. 1997. GABA in the mammalian suprachiasmatic nucleus and its role in diurnal rhythmicity. Nature 387:598-603.

Wagner S, Sagiv N, and Yarom Y. 2001. GABA-induced current and circadian regulation of chloride in neurones of the rat suprachiasmatic nucleus. J Physiol (Lond) 537:853-69.

Weber ET, Gannon RL, and Rea MA. 1995. cGMP-dependent protein kinase inhibitor blocks light-induced phase advances of circadian rhythms in vitro. Neurosci Lett 197:227-30. 
Wood NT, Haley A, Viry-Moussaid M, Johnson CH, van Der Luit AH, and Trewavas AJ. 2001. The calcium rhythms of different cell types oscillate with different circadian phases. Plant Physiology 125:787-96.

Yamaguchi S, Mitsui S, Miyake S, Yan L, Onishi H, Yagita K, Suzuki M, Shibata S, Kobayashi M, and Okamura H. 2000. The 5' upstream region of mPer1 gene contains two promoters and is responsible for circadian oscillation. Curr Biol 10:873-6.

Yamaguchi S, Kobayashi M, Mitsui S, Ishida Y, van der Horst GT, Suzuki M, Shibata S, and Okamura H. 2001. View of a mouse clock gene ticking. Nature 409:684.

Yamazaki S, Numano R, Abe M, Hida A, Takahashi R, Ueda M, Block GD, Sakaki Y, Menaker M, and Tei H. 2000. Resetting central and peripheral circadian oscillators in transgenic rats. Science 288:682-5.

Ying SW and Rusak B. 1997. 5-HT7 receptors mediate serotonergic effects on light-sensitive suprachiasmatic nucleus neurons. Brain Res 755:246-54.

Yokota S, Yamamoto M, Moriya T, Akiyama M, Fukunaga K, Miyamoto E, and Shibata S. 2001. Involvement of calcium-calmodulin protein kinase but not mitogen-activated protein kinase in light-induced phase delays and Per gene expression in the suprachiasmatic nucleus of the hamster. $\mathrm{J}$ Neurochem 77:618-27.

Zhang DX and Rusak B. 1989. Photic sensitivity of geniculate neurons that project to the suprachiasmatic nuclei or contralateral geniculate. Brain Res 504:161-4. 


\section{Figure legends}

Figure 1. A schematic illustration of the cellular signaling processes underlying circadian phase-shifts (i.e., resetting) caused by nocturnal light. Environmental light stimulation of retinal ganglion cells activates SCN neurons via the glutamatergic retinohypothalamic tract (RHT). Glutamate (Glu) released at the pre-synaptic terminus may be negatively regulated by serotonin $1 \mathrm{~B}$ receptors $\left(5 \mathrm{HT}_{1 \mathrm{~B}} \mathrm{R}\right)$. Both AMPA/kinate glutamate receptors (non-NMDAR) and NMDA receptors (NMDAR) are expressed on SCN neurons, and $\mathrm{Ca}^{2+}$ influx through NMDAR may have a critical role in RHT-SCN transmission. NMDAR-mediated $\mathrm{Ca}^{2+}$ responses at the post-synaptic membrane are also negatively regulated by $5 \mathrm{HT}_{1 \mathrm{~A} / 7} \mathrm{R}$ and orphanin-FQ/nociceptin receptors (OFQ/NR). The intracellular $\mathrm{Ca}^{2+}$ activation of ryanodine receptors (RyR) triggers further $\mathrm{Ca}^{2+}$ release from ryanodine-sensitive internal $\mathrm{Ca}^{2+}$ stores. This process may activate $\mathrm{Ca}^{2+} /$ calmodulin-dependent protein kinases II (CaMKII). The translocation of activated CaMKII (aCaMKII) or direct activation of CaMKII by nuclear $\mathrm{Ca}^{2+}$ mobilization triggers phosphorylation of the cAMP response element binding protein (CREB). Phosphorylated CREB (pCREB) is a potent transcription factor for the clock genes, such as Per1. Increase of cytosolic $\mathrm{Ca}^{2+}$ late in the subjective night may activate additional $\mathrm{Ca}^{2+}$-dependent signaling cascades (grey) via nitric oxide synthase (NOS), nitric oxide (NO), and protein kinase G (PKG) that has been proposed to produce advance shifts in the circadian clock.

Figure 2. An example of a recording of the cytosolic $\mathrm{Ca}^{2+}$ concentration in an organotypic slice culture of SCN. Upper panels denote virtual color cytosolic $\mathrm{Ca}^{2+}$ levels. Yellow-green spots on the first panel indicate the approximate location of cell 
bodies of SCN neurons that expressed cameleon $\mathrm{Ca}^{2+}$ sensors. Temporal changes in cytosolic $\mathrm{Ca}^{2+}$ levels in four neurons (circled in the top left panel) were plotted in the bottom panel. Synchronous circadian oscillations were observed in the cytosolic $\mathrm{Ca}^{2+}$ concentrations in these neurons, although the circadian phases among them were slightly advanced or delayed.

Figure 3. A. A schematic illustration of the cellular output processes for the autonomous circadian cycles of clock genes. The oscillations in gene transcription/translation cycles may generate circadian rhythms in cytosolic $\mathrm{Ca}^{2+}$ concentrations presumably via the effects on release of $\mathrm{Ca}^{2+}$ from ryanodine-sensitive internal $\mathrm{Ca}^{2+}$ stores. The hypothetical targets for clock gene regulation are located at ryanodine receptors (RyR) and mitochondria (Mt), which indirectly modulate RyR activity via cyclic ADP ribose (cADPR). The circadian rhythms in cytosolic $\mathrm{Ca}^{2+}$ concentrations may cause rhythmic neurotransmitter release and action potential firing rhythms in SCN neurons, although several other intermediate steps may be involved. B. The circadian cytosolic $\mathrm{Ca}^{2+}$ rhythms may be involved in the generation of gene transcriptional cycles in SCN neurons, because $\mathrm{Ca}^{2+}$ release from ryanodine-sensitive internal $\mathrm{Ca}^{2+}$ stores is a principal signaling process for the resetting of clock gene oscillations by nocturnal light (see Fig. 1 for details). This raises the possibility that circadian cytosolic $\mathrm{Ca}^{2+}$ rhythms may mediate not only the output signaling processes from the clock gene oscillations, but also the input signaling processes that generate clock gene oscillations in SCN neurons. 


\section{SCN neuron}

Light

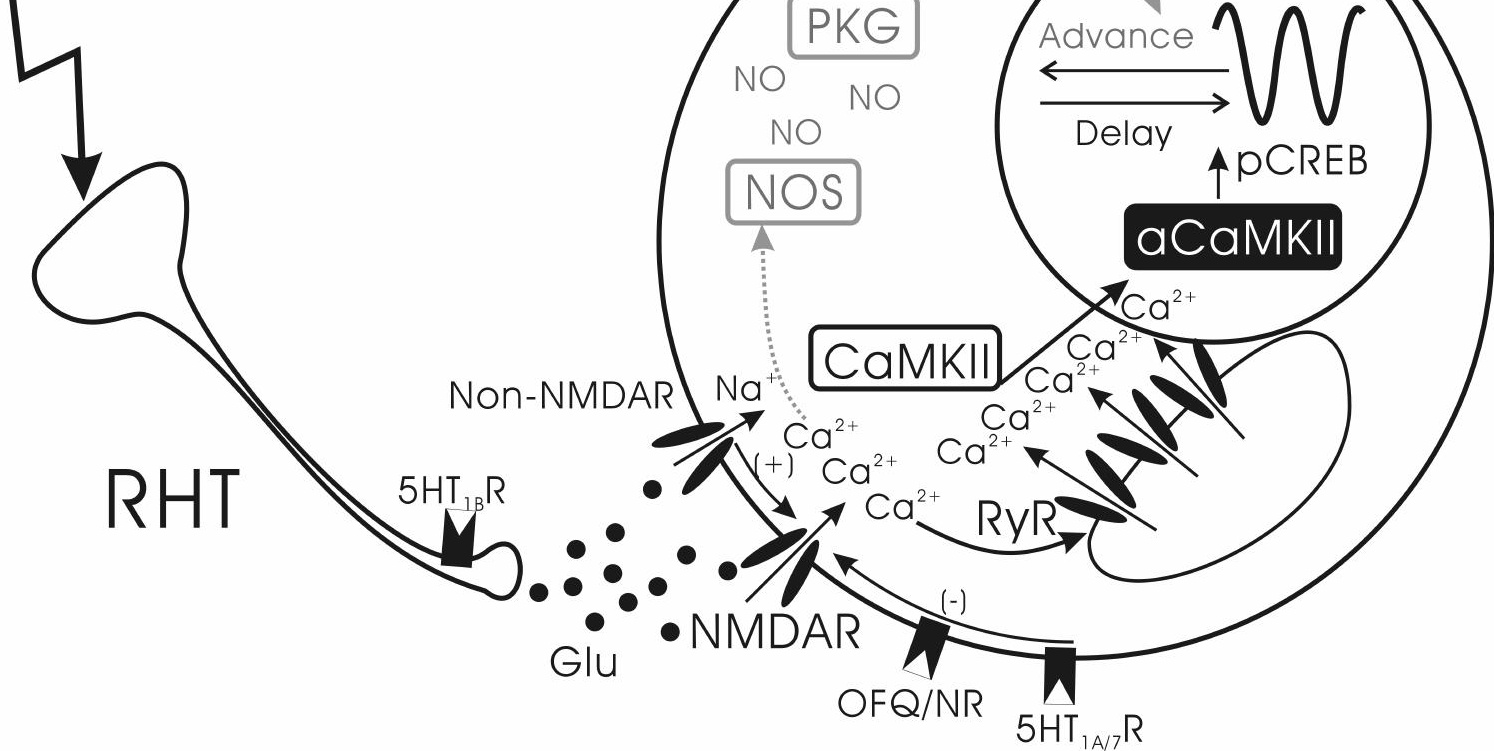




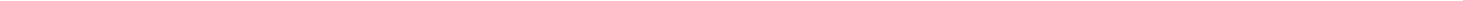




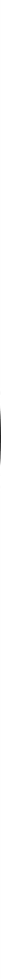

